\title{
橋梁構造形式と桁上走行自動車の 地震時事故率に関する解析的研究
}

\author{
高田＼cjkstart至郎 1 ・山本 聡 2 鍬田 泰子3 \\ 1フェロー会員 神戸大学教授 工学部建設学科（テ657-8501 神戸市灘区六甲台町1-1） \\ E-mail:takada@kobe-u.ac.jp \\ 2学生会員 神戸大学自然科学研究科（广657-8501 神戸市灘区六甲台町1-1） \\ E-mail:034t145n@y03.kobe-u.ac.jp \\ 3正会員 神戸大学助手 工学部建設学科（广657-8501 神戸市灘区六甲台町1-1） \\ E-mail:kuwata@kobe-u.ac.jp
}

\begin{abstract}
ゴム支承や免震支承を用いた橋梁では，構造系が長周期化して桁の応答変位が増大する可能性がある. 耐震設計あるいは免震設計によって橋梁の安全性が構造的に保たれたとしても，橋梁桁上を走行する利用 者の安全怢別途検討する余地がある. 寸なわち, 構造物および利用者からの両視点での安全性の検討が必 要である，そこで，本研究では地震発生時にゴム支承を有する高架橋を走行するドライバーの安全性を解 析的に検討し，ドライバーの視点での橋梁の安全性向上のための対策法について提案した.
\end{abstract}

Key Words : rubber bearing, Distinct Element Method(DEM), driver safety, elevated bridge

\section{1.はじめに}

兵庫県南部地震における阪神高速 3 号線に代表される ように橋梁に甚大な被害が発生し, 被災の経験をふまえ て道路橋示方書が見直された. 平成 8 年 12 月に改定さ

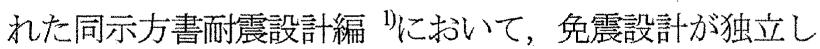
た章として初めて取り上げられたこともあり，新設なら びに既設の橋梁において，ゴム支承や免震支承が急速に 採用されつつある. ゴム支承や免震支承を用いる際の課 題については数多く報告されている23,334. 活么支承を設 置した橋梁では，固有周期が延びることにより枌の応答 変位が増大寸る傾向があるため，隣接析間の掛讨違い部 や析-橋台間に衝突が生じる可能性がある。この桁間衝 突問題に関する研究としては，渡辺・川島 ${ }^{2)}$ ，および武 野・伊津野 ${ }^{33}$ の研究がある。渡辺・川島は, 桁間衝突の 現象を橋标が衝突した時にのみ剛性を持つ衝突バネを用 いて表し，その解析精度に関しても検討している.また， 武野・伊津野は，衝突時における相対速度に着目し，構 造系の固有周期差比をもとに衝突速度スペクトルを作成 した．桁の落下を防ぐ落橋防止構造に関する研究には, 著者ら ${ }^{4}$ の研究がある. 著者らは，落橋防止構造に使用 する設計地震荷重の信頼性を橋梁全体でモデル化を行い, さらに支承破懐を考慮して落橋防止構造に作用寸る力と 支承の摩擦係数や地震動々の関係及び動的効果や一連の 挙動に対寸る工学的評価式を提案している.

橋梁上を走行する車両に関する研究として川谷ら 5),
の研究がある.川谷らは, 3 次元の車両モデルと主桁・ 横桁を梁要素, 床板を板要素とした有限要素を用いて動 的応答解析を行い，実測值と比較することにより妥当性 を検証している. また, 路面の凹凸や桁端段差などを車 両が通過する際に床板に及ぼす影響を明らかにしている. しかしながら，これらの研究は構造的な問題が中心であ り，利用者である桁上を走行するドライバーの地震時安 全性についてはほとんど着目されていない。

地震時の走行車両の応答やドライバーの反応に関する 研究として, 丸山ら ${ }^{7,8,99}$ の研究がある. 丸山らはドライ ビングシミュレータを用いて高速走行車両の地震時の挙 動を明らかにし，さらに6軸動摇装置を有したドライビ ングシミュレータを用いることによって現実感の高い地 震時の運転シミュレーションを行い，ドライバーの反応 について検討を行っている. 耐震設計あるいは免震設計 による橋梁の安全性が構造的に保たれたとしても橋梁桁 上を走行する利用者の安全は別途検討の余地がある。す なわち，構造物および利用者の両視点から安全性の検討 が必要である.

本研究では，個別要素法（Distinct Element Method，以 下 "DEM” と略す）を用いて，ゴム支承を有する高架橋 を走行している車両を対象に，地震を受けた際の橋梁お よび車両の挙動を一体的な解析により検討し，それらを 基に車両の事故率を算出した，その結果より，ドライバ 一からみたゴム支承を有する高架橋の安全性を向上させ るための対策について検討している. 


\section{2. 橋梁系と走行車両のモデル化および解析手法}

本研究では，橋梁桁上を走行する車両やゴム支承部の 破壊後の運動を考慮するため, Ivanov and Takada ${ }^{10}$ によっ て改良された 3 次元 DEM プログラムを用いて検討を行 う. 本解析法は不連続面で区切られた要素の集合体にお いて, 要素ごとに独立した 2 階常微分運動方程式を立て, これを差分近似して，時閒領域で前進的に解くことによ り要素の挙動を追跡し, その集合体としての動的挙動を 解析しようとするものである ${ }^{11}$. 本研究では，小要素の 集合体の挙動を取り扱うだけではなく，要素間をはりで 連結することで曲げや㸚じりを考慮した挙動を可能にし ている. また, 多角形モデルの剛体挙動もシミュレート 可能である. 各部のモデル化は以下に示す.

\section{(1) 橋梁のモデル化}

解析対象橋梁は図-1に示す5径間鋼桁橋である．本橋 梁は, 著者らの既往研究4)で用いた橋梁と同じものであ る.また，桁の条件として連続桁（5径間連続鋼桁橋： 以下連続桁橋という）と単純桁 (5径間単純鋼析橋 : 以 下単純桁橋という）の2種類をモデル化した.

\section{a) 上部工の解析条件}

上部工の解析条件については以下に示す通りで女る. 形式 : 5 径間鋼 $I$ 枌橋（地震時水平力分散構造） 支間割 : $40 \mathrm{~m} \times 5$ 径間 幅員: 全幅員 $12.000 \mathrm{~m}$ 支持条件 : 水平方向はすべて弾性支持 支承の種類 : ゴム支承 (タイプB)

桁 : 連続桁橋サイズが $200 \mathrm{~m} / 12 \mathrm{~m} / 0.4 \mathrm{~m}(\mathrm{~B} / \mathrm{L} / \mathrm{H}) \times 1$

: 単純析橋サイズが $40 \mathrm{~m} / 12 \mathrm{~m} / 0.4 \mathrm{~m}(\mathrm{~B} / \mathrm{L} / \mathrm{H}) \times 5$

\section{b) 下部工の解析条件}

下部工の解析条件については以下に示寸通りである. 橋脚 : $\mathrm{T}$ 形橋脚 基礎 : 場所打ち杭 橋脚，基礎の使用材料については表-1に示す.

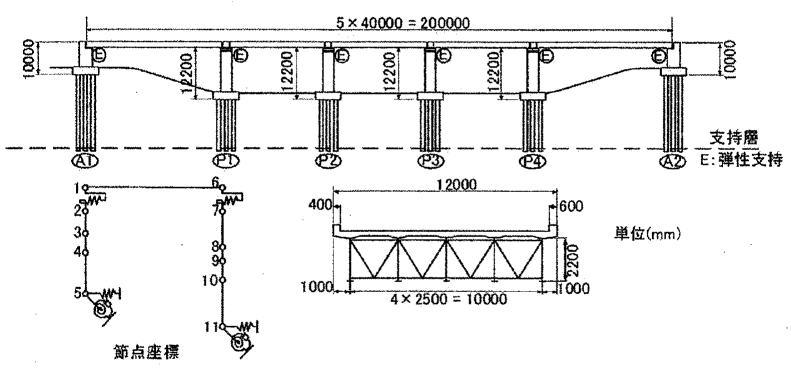

図-1 解析対象橋梁

表-1 下部工使用材料

\begin{tabular}{|c|c|c|}
\hline 部材 & コンクリート強度 & 鉄筋 \\
\hline 橋脚 & $\sigma_{c k}=21 \mathrm{~N} / \mathrm{mm}^{2}$ & \multirow{3}{*}{ SD295 } \\
\hline フーチング & $\sigma_{c k}=21 \mathrm{~N} / \mathrm{mm}^{2}$ & \\
\hline 杭 & $\begin{aligned} \sigma_{c k} & =21 \mathrm{~N} / \mathrm{mm}^{2} \\
\left(\sigma_{28}\right. & \left.=30 \mathrm{~N} / \mathrm{mm}^{2}\right)\end{aligned}$ & \\
\hline
\end{tabular}

\section{c) 解析条件}

ここで，図-1 に示す節点座標の一覧を表-2 に，橋台 と橋脚の諸量を表-3にそれぞれ示す．橋台・橋脚の減 衰定数は $2 \%$ とした． $X$ 方向は橋軸方向， $Y$ 方向は橋軸 直角方向， $Z$ 方向は鉛直方向である. 橋台と橋脚は弾性 3 次元のはりでモデル化を行った. 後述の入力地震動レ ベルでは橋脚は塑性化して，挙動はより複雑になると考 えられる.しかし, 本研究ではドライバーの危険度評価 に関与する影響要因の複雑さを避けるため, 橋脚は弾性 体とした，橋脚の塑性化による影響については，今後検 討が必要である. コンクリートの材料特性は, ヤング係 数 $E=2.35 \times 10^{7} \mathrm{kN} / \mathrm{m}^{2}$, せん断弾性係数 $G c=1.02 \times 10^{7} \mathrm{kN} / \mathrm{m}^{2}$ である。

桁は，支承が破壊した後，桁間に大きな変位が発生し て，桁自体のひずみは十分微小なものと考えられるため, 剛体とした. また，基礎の地盤バ市定数を表-4に示寸. 地盤は地盤種別種相当のバネ定数を与えた.

上部工重量は, 舗装や床板, 鋼重などをコンクリート に換算した断面としてモデル化した。 上部工全体の重量 は30,800kNであり，橋台上の反力は3,080kN（1橋台当た り），橋脚上での反力は6,160kN（1橋脚当たり）である.

表-2 節点座標

\begin{tabular}{|c|c|c|c|c|}
\hline Node & $X(\mathrm{~m})$ & $Y(\mathrm{~m})$ & $Z(\mathrm{~m})$ & 注䣋 \\
\hline 1 & 0 & 4 & -0.17 & \multirow{5}{*}{$\begin{array}{l}\text { A1橋台の值 } \\
\text { A2橋台については } \\
\text { X=200としたもの }\end{array}$} \\
\hline 2 & 0 & 4 & -2.55 & \\
\hline 3 & 0 & 4 & -5.1 & \\
\hline 4 & 0 & 4 & -7.27 & \\
\hline 5 & 0 & 4 & -14.37 & \\
\hline 6 & 40 & 4 & -1 & \multirow{6}{*}{$\begin{array}{l}\mathrm{P} 1 \text { 橋脚の値 } \\
\mathrm{P} 2 、 \mathrm{P} 3 、 \mathrm{P} 4 \text { 橋脚にこつい } \\
\text { てはそれぞれ=80、 } \\
\text { 120、160としたもの }\end{array}$} \\
\hline 7 & 40 & 4 & -2.5 & \\
\hline 8 & 40 & 4 & -6.25 & \\
\hline 9 & 40 & 4 & -10 & \\
\hline 10 & 40 & 4 & -12.2 & \\
\hline 11 & 40 & 4 & -17.3 & \\
\hline
\end{tabular}

表-3 橋台と橋脚の諸元

\begin{tabular}{|c|c|c|c|c|c|c|}
\hline 番号 & \multicolumn{2}{|c|}{ Node } & $A\left(\mathrm{~m}^{2}\right)$ & $I_{x}\left(\mathrm{~m}^{4}\right)$ & $I_{\gamma}\left(\mathrm{m}^{4}\right)$ & $I_{2}\left(\mathrm{~m}^{4}\right)$ \\
\hline 1 & 1 & 2 & 24 & 288 & 8 & 29 \\
\hline 2 & 2 & 3 & 24 & 288 & 8 & 29 \\
\hline 3 & 3 & 4 & 72 & 435 & 435 & 737 \\
\hline 4 & 4 & 5 & 38 & 70 & 20 & 175 \\
\hline 5 & 6 & 7 & 26 & 288 & 8 & 37 \\
\hline 6 & 7 & 8 & 11 & 23 & 4.5 & 13 \\
\hline 7 & 8 & 9 & 11 & 23 & 4.5 & 13 \\
\hline 8 & 9 & 10 & 72 & 435 & 435 & 735 \\
\hline 9 & 10 & 11 & 10 & 8 & 8 & 13 \\
\hline
\end{tabular}

表-4 基礎の地盤バネ定数

\begin{tabular}{|c|c|c|c|}
\hline & 橋台部 & 橋脚部 \\
\hline \multirow{4}{*}{$\begin{array}{l}\text { フーチング底 } \\
\text { 面の基礎の地 } \\
\text { 盤バネ定数 }\end{array}$} & Ass $(\mathrm{kN} / \mathrm{m})$ & $3.521 \times 10^{6}$ & $2.709 \times 10^{6}$ \\
\hline & Asr $(\mathrm{kN} / \mathrm{rad})$ & $-5.544 \times 10^{6}$ & $-4.357 \times 10^{6}$ \\
\hline & $\operatorname{Ars}(\mathrm{kN} \cdot \mathrm{m} / \mathrm{m})$ & $-5.544 \times 10^{6}$ & $-4.357 \times 10^{6}$ \\
\hline & $\operatorname{Arr}(\mathrm{kN} \cdot \mathrm{m} / \mathrm{rad})$ & $5.527 \times 10^{7}$ & $3.838 \times 10^{6}$ \\
\hline
\end{tabular}


支承は，一般的に多く用いられている積層ゴム支承 （タイプB）を対象としてモデル化を行った，その諸元 を表一5に示す， $k_{n}$ は鈆直方向（Z方向）の岡性を， $k_{\mathrm{s}}$ は橋 軸方向（X方向）の剛性を， $k_{3}$ は橋軸直角方向（Y方向） の剛性をそれぞれ示す，また支承破壊伸びに達するまで の水平バネは線形として図-2に示す $P$ - $\delta$ 関係を用いた. 図-2中の括弧内の值は連続部の支承の值である. 支承の せん断限界ひずみは $250 \%$ とし，その位置で破壊するも のとする ${ }^{4}$. 支承破壊後は積層ゴムと桁が切断されるた め, 水平方向には摩擦力のみ働くモデルを用いた. 本研 究では支承降伏後の履歷特性モデルは考慮しておらず, 履歷特性モデルとの精度比較の検討は今後は必要である。

落橋防止構造として表-6 に諸元を示寸 PC ケーブルを 用いた．また，現在の落橋防止構造は設計地震動に対し ては作動させず, 想定外の事態が発生した場合に作動さ せるという位置付けである，そこで本研究では全支承破 壞後に, 桁が橋軸方向に 0.550 (m) 移動してから力が作用 し始め, 力と変位量は線形関係にあるとした，桁-橋台 間の遊間距離については算出された栴遊間 $S_{B}=237(\mathrm{~mm})$ に若干の余裕量を加えて $250(\mathrm{~mm})$ とした. 単純桁橋の桁 間の遊間距離も同様にして 150(mm)とした。

\section{（2）車両のモデル化}

解析対象車両は高架橋上を多く走行していると考えら れる図-3に示寸小型普通乗用車 $(1,600 \mathrm{cc})$ 程度とした ${ }^{9}$. 車両モデルの入力パラメータ值を表-7に示す ${ }^{8)}$. ここで

\begin{tabular}{|c|c|c|} 
表-5 & ゴム支承の諸元 \\
\hline & 連続部 & 掛け違え部 \\
\hline 形状 $(\mathrm{B} / \mathrm{L} / \mathrm{h})(\mathrm{m})$ & $0.530 / 0.530 / 0.168$ & $0.680 / 0.680 / 0.096$ \\
\hline 断面積 $\left(\mathrm{m}^{2}\right)$ & 0.281 & 0.462 \\
\hline 支承破壊後の摩擦係数 & 0.3 & 0.3 \\
\hline$k_{n}(\mathrm{kN} / \mathrm{m})$ & $5.6 \times 10^{5}$ & $1.6 \times 10^{6}$ \\
\hline$k_{s x}(\mathrm{kN} / \mathrm{m})$ & 1,640 & 4,720 \\
\hline$k_{s y}(\mathrm{kN} / \mathrm{m})$ & 1,640 & 4,720 \\
\hline 支承ゴム高 $(\mathrm{m})$ & 0.168 & 0.096 \\
\hline 破断伸び $\delta_{u}(\mathrm{~m})$ & 0.42 & 0.24 \\
\hline
\end{tabular}

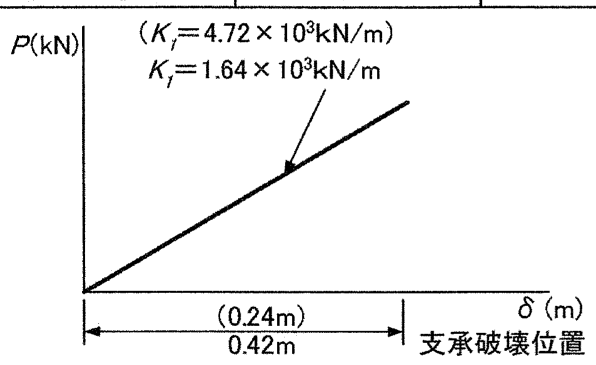

図-2 ゴム支承 $D P-\delta$ 関係

表-6 PCケーブルの諸元

\begin{tabular}{|c|c|}
\hline 面積 $\left(\mathrm{m}^{2}\right)$ & 0.00312 \\
\hline ケーブル長 $(\mathrm{m})$ & 3 \\
\hline ヤング係数 $\left(\mathrm{kN} / \mathrm{m}^{2}\right)$ & $2.0 \times 10^{8}$ \\
\hline せん断弾性係数 $\left(\mathrm{kN} / \mathrm{m}^{2}\right)$ & $7.7 \times 10^{7}$ \\
\hline 設置位置 & 上部工位置 \\
\hline 作用伸び $(\mathrm{m})$ & $0.55 \mathrm{~m}$ から作用開始 \\
\hline
\end{tabular}

バネ上質量は車両本体の質量を，バネ下質量は車輪質量 （タイヤ，ホイール，ブレーキパット等を含む）を表し ている.

車両の運動は 18 自由度系でモデル化した. 車体本体 に関する運動としては上下運動，進行方向回転運動，進 行直交方向回転運動，進行方向水平運動，進行直交方向 水平運動，鉛直軸回転運動である（図-4）。また，前軸， 後軸に関しても，車両の 6 運動と同様にそれぞれ 6 運動 がある，車体，前軸，後軸は，それ自体のひずみが微小 なものと考えられるので岡体としてモデル化した.

車両モデルの設定は，既往文献との比較の他，実車両 の自由振動実験による結果を反映してバネ定数および咸 衰を決定しており，モデルの妥当性は確認している ${ }^{12}$.

\section{(3) 全体系解析モデル}

上述した橋梁モデルと車両モデルを合わせた全体系で の解析モデルを図-5に示す.

車両の走行状態を解析で表現するために，本研究では 全てのタイヤ要素に車両を進行方向に進ませる強制モ一 メントを与える，また，走行する車両と路面との摩擦係 数は文献 ${ }^{13}$ に示されている乾いた舗装道路を走行してい る場合を想定し，かつ，速度条件を加味した表-8の摩擦

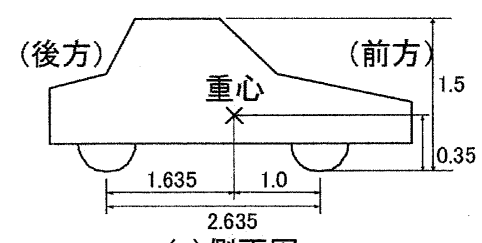

(a) 側面図

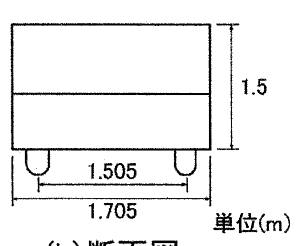

(b) 断面図
図-3 解析対象車両

表-7 車両モデルのパラメータ值

\begin{tabular}{|c|c|}
\hline バネ上質量 $(\mathrm{kg})$ & 1100 \\
\hline バネ下算量 $(\mathrm{kg})$ & 100 \\
\hline 重心高 $(\mathrm{m})$ & 0.35 \\
\hline タイヤ縦バネ定数 $(\mathrm{kN} / \mathrm{m})(4$ 本で $)$ & 784 \\
\hline サスペンジバネ定数 $(\mathrm{kN} / \mathrm{m})(4$ 本で $)$ & 137.2 \\
\hline タイヤ減衰項 $(\mathrm{Ns} / \mathrm{m})(4$ 本で) & 98 \\
\hline サスペンション減哀項 $(\mathrm{kNs} / \mathrm{m})(4$ 本で $)$ & 4.9 \\
\hline
\end{tabular}

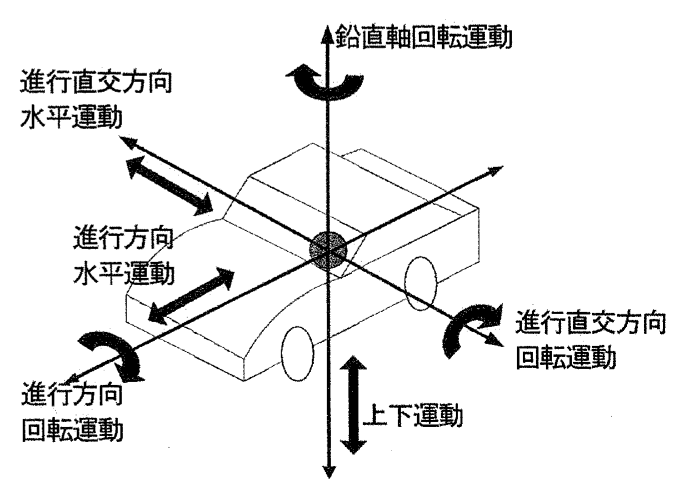

図-4 車両の運動モデル 
係数の值を用いた.

桁間および枌-橋台間で大きな相対変位が発生した状 態での車両の通過安全性を検討寸る必要がある。 そこで 本研究では以下に示寸ような方法を用いた. 図-6のよ うにタイヤに水平力 $F=1(\mathrm{kN})$ が発生したときに中心 $P$ に 発生する水平力 $F^{\prime}$ は, 力 $F$ の中心 $P$ 方向成分の $\cos \theta$ をとることから $F$ の作用位置の関数として式(1)で表さ れる。

$$
F^{\prime}=F \cos ^{2} \theta
$$

また，Fの作用位置はタイヤの落下量によって変化する. このタイヤの中心に㗢く水平力 $F^{\prime}$ が直接車体に受け渡 されるものと仮定し，この水平力を用いて検討を行う. 車両が大きな水平力を受けるとエアバックが作動する. エアバックの作動条件は，一般的に時速 $20 \mathrm{~km} \sim 30 \mathrm{~km}$ 以 上の速度で硬い壁などに正面衝突した時，及びそれと同 等の衝撃を受けた時，つまり，ある值以上の進行方向の 水平力を感知した時と規定されている. 時速 $20 \sim 30 \mathrm{~km}$ 以上の速度で硬い壁などに正面衝突した時に発生する水 平力 $F_{m a x}$ は車両の質量 $m$ と時速 $v$ を用いて力積により算出 することができる. そこで, タイヤの中心の水平力 $F^{\prime}$ の $F_{\text {mar }}$ に対する超過条件で車両が安全に通過可能である かを判定する. 同速度でもタイヤの落下量が大きいと水 平との方向角 $\theta$ が小さくなるのでタイヤの中心に作用寸 る水平力は大きくなる（図一）。

本手法により算出した車速の速度と許容落下量の関係 を図-8に示寸. 図-8より式(2)が得られる. 相関係数は,

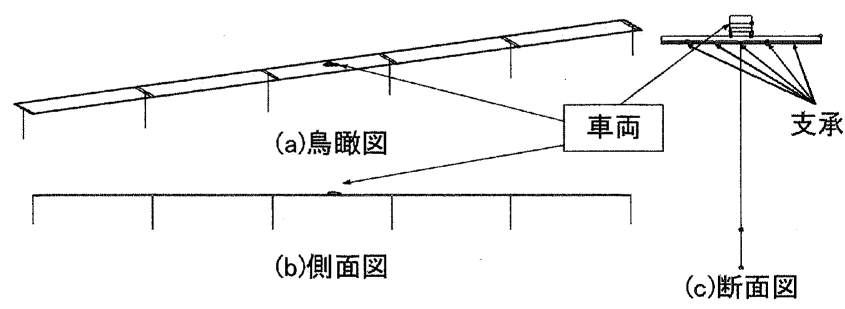

図-5 解析モデル

表-8 車速と摩擦係数との関係 ${ }^{13)}$

\begin{tabular}{|c|c|c|c|c|c|c|c|c|c|}
\hline 車速 $(\mathrm{km} / \mathrm{h})$ & 20 & 30 & 40 & 50 & 60 & 70 & 80 & 90 & 100 \\
\hline 摩擦係数 & 0.60 & 0.59 & 0.58 & 0.55 & 0.53 & 0.50 & 0.47 & 0.47 & 0.47 \\
\hline
\end{tabular}

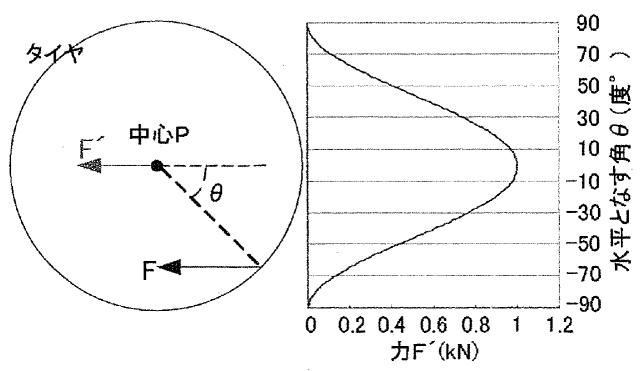

図-6 Fの作用位置と中心に衝く水平力との関係
$R^{2}=0.995$ であり，概ねタイヤの落下量 $y(\mathrm{~m})$ と車速 関係を表現できているものと考えられる.

$$
y=2.61 v^{-1.12}
$$

桁間および析-橋台間の伸縮装置については道路橋示 方書りにもとづいて受け持ち変位を $10 \mathrm{~cm}$ とした.

\section{(4) ドライバーの反応の評価法}

次に橋梁桁上で地震を受けたドライバーの反忘につい て検討寸る. ドライバーの安全性を解析的に検討するに あたりドライバーの反応は非常に重要な要素である. 本 研究では, 新潟県中越地震の際に実施したアンケートか ら得られたドライバーの反応特性を解析的に表現するこ とを試みた。このアンケート調查は，新潟県中越地震時 に長岡市・小千谷市周辺で乗車していたタクシードライ バーを主な回答者として実施したものである. 質問項目 は, 地震時の車両挙動とドライバーの反応に関するもの である. 有効回答数は48件であった．本調查の詳細は, 拙著論文 ${ }^{14)}$ を参考にされたい.

\section{a）ドライバーが地震に気付く震度の導入}

回答者が本震や余震時にいた市町村の気象庁発表の震 度階とドライバーの反応に関してアンケートを整理した 結果，走行中のドライバーは震度 5 弱以上の市町村にい た回答者は全員摇れに気付いている. そこで，本研究で は震度 5 弱に達するとドライバーが地震に気付くとした。 この值は, 気象庁震度階と計測震度との関係加, 計測 震度 4.5 (震度 5 弱の下限値) に相当する. さらに, こ れを解析的に導入するために，著者らによって開発され た瞬間計測震度 ${ }^{15}$ を用いた。

一般に計測震度は，対象とする 3 成分の波形をフィル ター処理し，その3成分波形を合成したベクトル波の絶

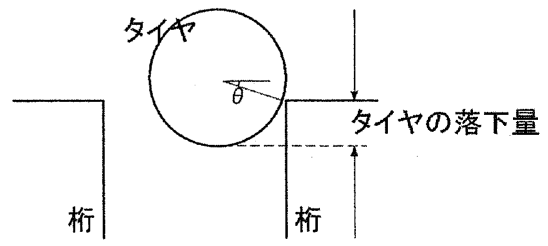

図-7 タイヤの落下量

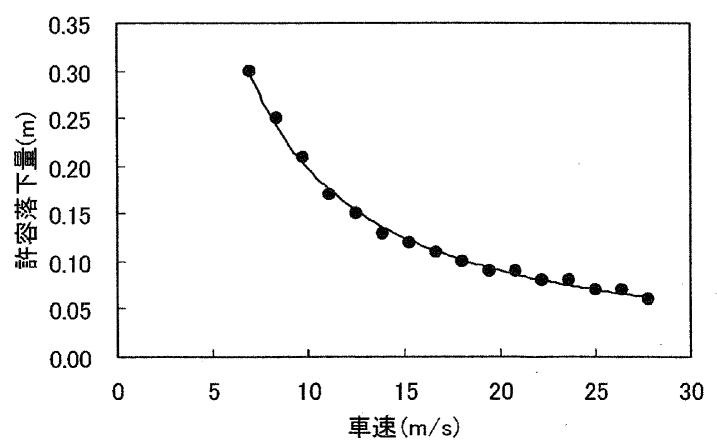

図-8 タイヤの許容落下量と車速の関係 
対值があるレベル以上で継続時間を満たす場合に，その 值を河角の式に代入して，算出される．瞬間計測震度法 では一つの地震動のピーク值ではなく, ベクトル波形を 短い単位時間（本研究では 0.5 秒間）ごとに分割し，単 位時間内での継続時間を満たす最大值を算出した計測震 度を瞬間計測震度と呼ぶ．本指標により，時間ごとの震 度の変化を把握することができる．もとの波形を単位時 間に分けて震度を算出するため, 波形によっては計測震 度よりも瞬間計測震度の最大值が $0.2 \sim 0.3$ 程度小さくな ることが確認されているが，多くは計測震度と同じ值を とる.

\section{b) ブレーキの導入}

アンケート調查結果より，ドライバーが地震の摇れに 気付いたのち全てのドライバーはブレーキを掛けている. そこで，ドライバーが地震に気付いた後，プレーキを踏 み停車寸るとする。 つまり, 瞬間計測震度值が 4.5 に達 したらドライバーは停車するまでブレーキをか㚈るとい う条件を導入した. アンケート結果によると, 地震に気 付いた後に急ブレーキをかけている人が少ないことから， 急ブレーキではなく通常のブレーキで車両を停車させる ものとした. その際に用いる速度と停止距離の関係 ${ }^{13}$ を 図-9に示す。ここで空走距離とはドライバーがブレーキ を踏むと決めてから実際にブレーキを踏むまでの時間内 に進む距離のことで，ここでは1秒間で進む距離として いる．制動距離とはブレーキを踏み始めてから停止する までの距離のことである. 兵庫県南部地震の際にJR鷹取 駅て観測された波形を対象とした際の瞬間計測震度值を 図-10に示寸，これより，計測震度值4.5に達するのは地 震発生後 2.0 秒後であることが分かる．また，時速 $60 \mathrm{~km} / \mathrm{h}$ の場合に2秒後からブレーキを考慮した際の車両の速度， 変位の解析結果を図-11に示寸，図-11(a)よりおよそ7.0秒 付近で車両が停車していることが分かる．また，図-11 (b)よりブレーキをかけ始める2秒後の位置までの距離が

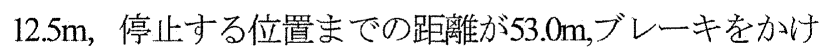
て停車するまでの距離が40.5m であり, 図-9の結果と整 合していることが分かった.

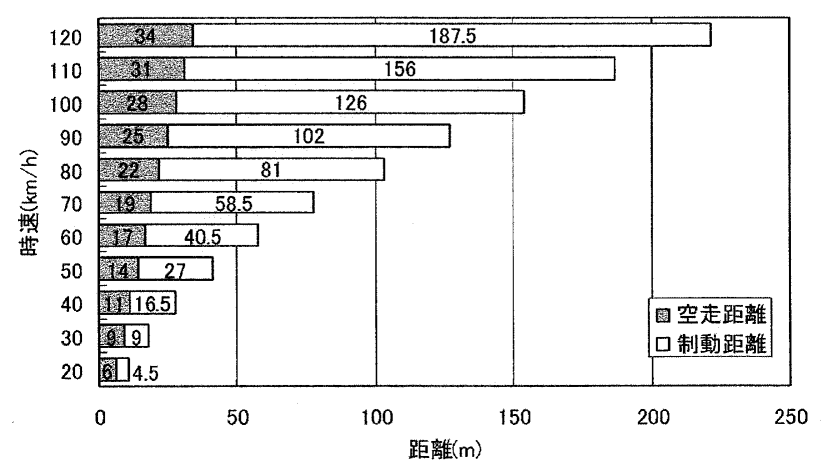

図-9 速度と停止距離の関係 ${ }^{14)}$

\section{3. 走行自動車事故率の算出}

\section{(1) 解析ケース}

地震時に橋梁桁上を走行している車両を解析対象とす る. 解析対象橋梁については連続桁橋と単純桁橋の 2 種 類とした. 入力地震動は本解析モデル橋梁の 1 次モード の固有周期に地震動卓越周期が 1 番近く, 共振を引き起 こす可能性が高い兵庫県南部地震の際に JR 鷹取駅で観 測された波形（以下，鷹取波とよぶ）を用いた．入力地 震動の設定にあたり，兵庫県南部地震の強震記録の他， 鳥取県西部, 芸予, 三陸南，十勝沖，新潟県中越地震の 強震記録（全 23 記録）を用いて入力地震動の周期特性 と橋梁の地震応答の関係について事前に検討した. 本研 究の対象橋梁は, 兵庫県南部地震のようなやや周期の長 い地震動では支承破壞をするが，他の多くの地震動では 支承は健全であることを確認している。

また，地震動と橋梁，車両との地震応答の関係につい ては, 車両や析の応答加速度や震度, 応答変位などの指 標で検討した．支承破壊後は摩擦力を伴って桁が滑るた めに桁や車両の応答変位は大きくなるが，応答加速度は 小さくなる，そして，桁と橋台や桁間で衝突が発生する と瞬間的に桁に非常に大きな応答加速度が生じるが，そ の外力レベルに対寸る車両応答は滑りとして表れ，桁の 大きな応答加速度は車両に伝達されない，とくに，橋梁 の地震応答は非常に複雑であるため, 車両の安全性評価 には車両の応答加速度や震度值よりもむしろ車両の寸心゙ りで説明するほうが分かりや寸い，したがって，本稿で は車両のす心゙りを主な評価項目とする.

モデルの橋梁では全幅員 $12 \mathrm{~m}$ であるのでこれを 3 車 線に分割した（図-12）。一般的に 1 車線の幅は一般道 では $2.75 \sim 3.5 \mathrm{~m}$, 高速道路では $3.25 \sim 3.5 \mathrm{~m}$ 程度になって

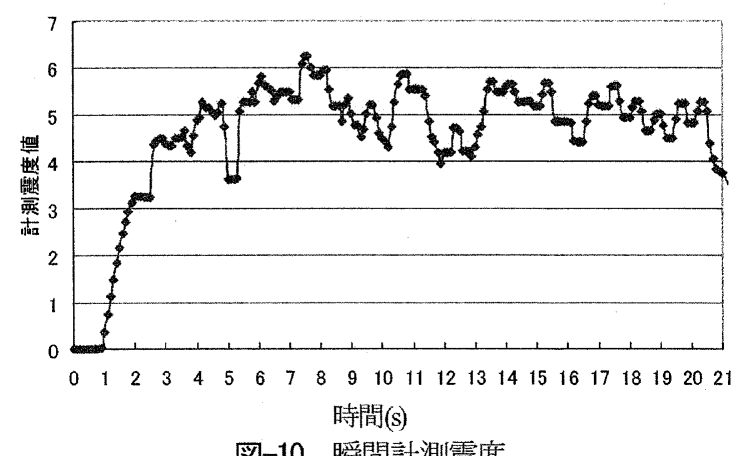

図-10 瞬間計測震度

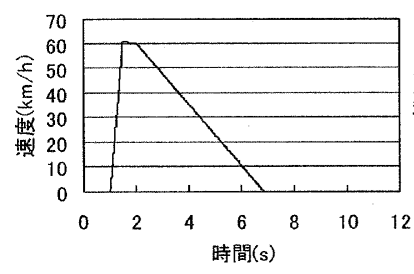

(a)車両の速度

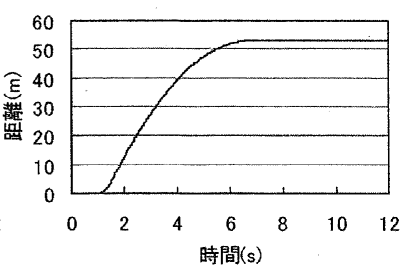

(b)車両の変位
図-11 車両の時刻歷波形 
いる.ここでは高架橋の特性上，高速走行車両が多いと

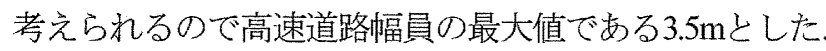
車両の速度は $60 ， 80,100 \mathrm{~km} / \mathrm{h}$ のケースで解析を行っ た。橋梁上を走行中に地震が発生すれば必ず車両は橋梁 上で地震を受ける．また，車両が橋梁に差し掛かる前に 地震が発生した場合でも橋梁上で地震を受ける可能性が ある，そこで，橋梁上を走行している車両を対象とし， 車両速度と計測震度4.5に達するまでの時間から算出さ れる走行距離と空走距離, 制動距離を算出することによ り地震発生時の車両位置の範囲を決定した．解析開始の 車両の位置は，橋梁に差し掛かる場所から $20 \mathrm{~m}$ 間隔に配 置してある.図一13は各初速度の解析ケースにおける車 両の進行開始位置を示している．それぞれの位置で，車 両が右車線, 中央車線, および左車線にある場合の3ケ 一スを考慮した．すなわち，60，80，100km/hの車速で， それぞれ42，51，60ケースの走行車両について解析した.

\section{（2）事故率の算出法}

車両の事故率算出の際に考慮した走行車両の事故要因 については以下に示す通りである. ドライバーがブレー キをかけたことによる玉突き事故や車両同士の衝突事故 などに関してはドライバーの反灾特性によるものが大き い. また，スリップを起こしている場合にドライバーが ハンドルをきるなどの運転行動で車両の運動を完全に制 御することは不可能である.これらのことから本研究で 恃ドライバーの反応特性に起因する事故については考慮 せずに，ドライバーがアンケートで得られた地震時の反

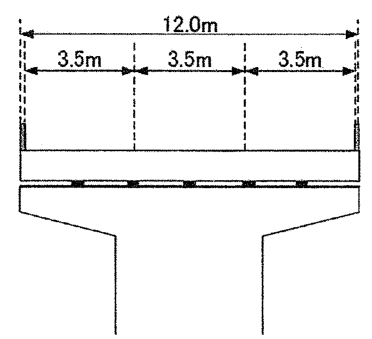

図-12 橋梁断面図
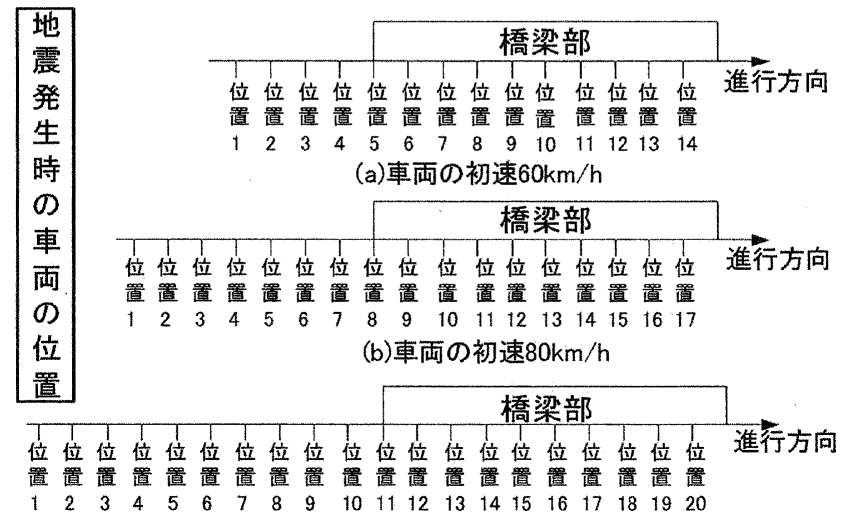

(c)車両の初速 $100 \mathrm{~km} / \mathrm{h}$

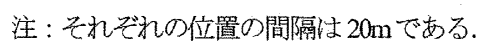

図-13 解析ケース
応特性のみを行ったとして発生する可能性がある事故に ついて考慮した。事故攵ースを以下に示す.

Case(1) 車両がスリップしたことにより壁面へ衝突し た場合

Case(2) 桁の橋軸直角方向のずれにより車両が壁面へ の衝突および通行不可になった場合

Case(3) 桁間および杕-橋台間の開きにより車両が通行 不可になった場合

Case(4) 車両がスリップすることにより走行車線を逸 脱した場合

Case(5) 桁の橋軸直角方向のずれにより走行車両を逸 脱した場合

次に事故率は，Case(1)〜Case(5)の事故を起こした車両 数を各車速で考慮した車両数で除した值として定義した. なお，Case(4)および Case(5)は車線逸脱を起こしたケース で，他のケースのように直接的な事故ではない.この2 つのケースを起こした車両は車両数を 0.5 台と仮定した.

\section{(3) 事故ケースと事故率}

まず，車速60km/hの際に発生した事故ケースを表-9に 示す，事故を起こさず停車した，および橋梁部を通過し たケースはNと記載した. 表-9より単純桁橋でも地震発 生時の車両の位置が同心位置2の際にのみ事故が発生し ていることが分かる，事故のケースも同じであり，左車 線および中央車線ではCase(4)，右車線ではCase(1)のケ一 スである.これは，車線の位置に関わらず車両がスリッ プして右にずれたことにより左車線および中央車線を走 行していた車両は車線冕脱で斉んだが，右車線を走行し ていた車両は右壁面へ衝突したことを示している.

次に，車速 $80 \mathrm{~km} / \mathrm{h}$ 際に発生した事故ケースを表-10 に示す．表-10より車速が $60 \mathrm{~km} / \mathrm{h}$ の際と比べてかなり事 故が多く発生していることが分かる．また，地震発生時 の位置12以降の車両は地震動が強震域に達寸る前に橋梁 部を通過していたことより橋梁部での事故にはつながら なかった. 連続析橋, 単純桁橋共にスリップに起因して いるCase(1)およびCase(4)が事故の大部分を占めているこ とがわかる。

表-9 車速 $60 \mathrm{~km} / \mathrm{h}$ 際の事故ケース

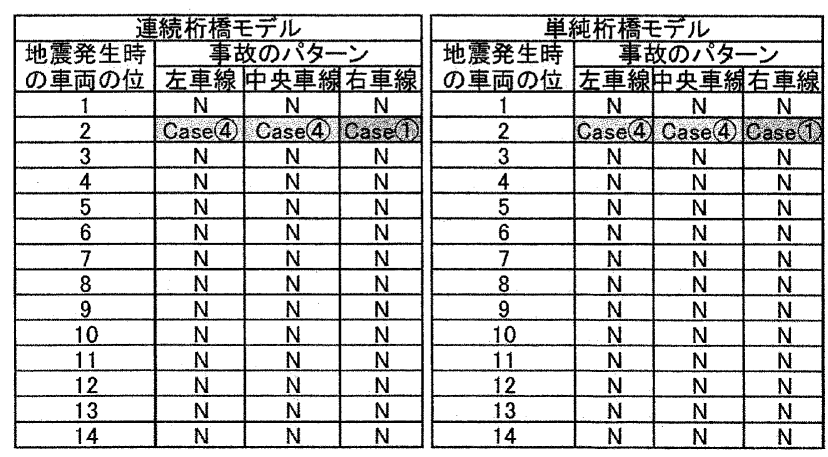


次に，車速100kmhの際に発生した事故ケースを事故 表-11に示す. 表-11より他の車速に比べて連続桁橋と単 純桁橋で顕著に差が現れていることが分かる．連続桁橋 の中央車線ではCase(1)およびCase(2)の事故が無いのに対 して単純桁橋モデルでは中央車線においてもCase(1)よ びCase(2)の事故が発生していることが分かる．また，単 純桁橋モデルの左車線ではCase(3)事故が3ケース発生し ていることも見てとれる. 同時にCase(2)，Case(5)の事故 も顕著に見られる.これらは桁同士の橋軸方向および橋 軸直角方向に発生する相対変位（ずれ）に大きく関係し ていると考えられる. 地震発生時の位置15以降の車両は 地震動が強震域に達寸る前に橋梁部を通過していたこと より橋梁部で事故にはつながらなかった.

次に, 各車速での事故率をまとめたものを図-14に示 す.ここに示した事故率は各車線で求めた事故率の平均 值である. 図-14より，車速60 kmhでの事故率が他に比 べて非常に小さい值になっている. 車速が60kmhの場合， 車両は地震発生後7 8秒程度で停車している. このこと より, 車速が $60 \mathrm{~km} / \mathrm{h}$ 以下ケースでは地震動の強震域に 達する前に車両が停車していることに起因して事故率が 小さくなっていると考えてよい。車速 $80 \mathrm{~km} / \mathrm{h}$ おうび $100 \mathrm{~km} / \mathrm{h}$ ケケースでは単純桁橋のほうが連続析橋に比べ

表-10 時速 $80 \mathrm{~km} / \mathrm{h}$ の際の事故ケース

\begin{tabular}{|c|c|c|c|c|c|c|c|}
\hline \multicolumn{4}{|c|}{ 連続桁橋モデル } & \multicolumn{4}{|c|}{ 単純桁橋モデル } \\
\hline 地震発生時 & & 走行位歪 & & 地震発生時 & & 走行位置 & \\
\hline の車画の位 & 左車線 & 审英車䋨 & 右車線 & の車画の位 & 左車䊽 & 央央董繶 & 右重線 \\
\hline 1 & Case 5 & Case $(5)$ & Case(2) & 1 & Case 1. & Case (4) & Case (4) \\
\hline 2 & Case (1 & Case (4) & Case (4) & 2 & Case 1 & Case (4) & Case(4) \\
\hline 3 & $\mathrm{~N}$ & $\overline{\mathrm{N}}$ & $\mathrm{N}$ & 3 & Case(1) & Case(4) & Case(4) \\
\hline 4 & $\mathrm{~N}$ & $\mathrm{~N}$ & $\mathrm{~N}$ & 4 & Case(4) & Case (4) & Cased \\
\hline 5 & Case (4 & Case (4) & Case(1) & 5 & Case (4) & Case(4) & Case(1) \\
\hline 6 & Cased & Case (4) & Case (4) & 6 & Case (4) & Case(4) & Case(1) \\
\hline 7 & Gased & Case (4) & Case (4) & $\frac{7}{7}$ & Case(2) & Case(5) & Case(5) \\
\hline 8 & Cased & Case (4) & Case (4) & 8 & $\mathrm{~N}$ & $\mathrm{~N}$ & $\mathrm{~N}$ \\
\hline 9 & Case. (1 & Case (4) & Case (4) & 9 & Case (4) & Case (4) & Casen \\
\hline 10 & Cased 1 & Case (4) & Case (4) & 10 & Case(5) & Case(5) & Case2 2 \\
\hline 11 & Cased 1 & Case (4) & Case(4) & 11 & Case (4) & Case (4) & Case(1) \\
\hline 12 & $\mathrm{~N}$ & $\mathrm{~N}$ & $\mathrm{~N}$ & 12 & $\mathrm{~N}$ & $\mathrm{~N}$ & $\mathrm{~N}$ \\
\hline 13 & $\mathrm{~N}$ & $\mathrm{~N}$ & $\mathrm{~N}$ & 13 & $\mathrm{~N}$ & $\mathrm{~N}$ & $\mathrm{~N}$ \\
\hline 14 & $\mathrm{~N}$ & $\mathrm{~N}$ & $\mathrm{~N}$ & 14 & $\mathrm{~N}$ & $\mathrm{~N}$ & $\mathrm{~N}$ \\
\hline 15 & $\mathrm{~N}$ & $\mathrm{~N}$ & $\mathrm{~N}$ & 15 & $\mathrm{~N}$ & $\mathrm{~N}$ & $\mathrm{~N}$ \\
\hline 16 & $\mathrm{~N}$ & $\bar{N}$ & $\mathrm{~N}$ & 16 & $\bar{N}$ & $\mathrm{~N}$ & $\mathrm{~N}$ \\
\hline 17 & $\mathrm{~N}$ & $N$ & $\mathrm{~N}$ & 17 & $\bar{N}$ & $\mathrm{~N}$ & $\mathbf{N}$ \\
\hline
\end{tabular}

表-11 車速 $100 \mathrm{~km} / \mathrm{h}$ の際の事故厅ース

\begin{tabular}{|c|c|c|c|}
\hline \multicolumn{4}{|c|}{ 連経枌橋モデル } \\
\hline $\begin{array}{l}\text { 地震発生時 } \\
\text { の車両の位 }\end{array}$ & 左車線 & 走行位品 & 悬右線 \\
\hline 1 & Case (5) & Case 5 & Case? \\
\hline 2 & Case (1) & Case 5 & Gase(2) \\
\hline 3 & $\mathrm{~N}$ & $\mathrm{~N}$ & $\mathrm{~N}$ \\
\hline 4 & Gasen 1 & Case (4) & Case(4) \\
\hline 5 & CaseO & Case (4) & Case (4) \\
\hline 6 & Case (1) & Gase (4) & Case (4) \\
\hline 7 & $\mathrm{~N}$ & $\mathrm{~N}$ & $\mathrm{~N}$ \\
\hline 8 & $\mathrm{~N}$ & $\mathrm{~N}$ & $\mathrm{~N}$ \\
\hline 9 & $\mathrm{~N}$ & $\mathrm{~N}$ & $\mathrm{~N}$ \\
\hline 10 & Cased 1 & Case (4) & Case (4) \\
\hline 11 & Gase 1 & Case (4) & Case (4) \\
\hline 12 & Cased & Case (4) & Case (4) \\
\hline 13 & $\mathrm{~N}$ & $\mathrm{~N}$ & $\mathrm{~N}$ \\
\hline 14 & $\mathrm{~N}$ & $\mathrm{~N}$ & $\mathrm{~N}$ \\
\hline 15 & $\mathrm{~N}$ & $\mathrm{~N}$ & $\mathrm{~N}$ \\
\hline 16 & $\mathrm{~N}$ & $\mathrm{~N}$ & $\mathrm{~N}$ \\
\hline 17 & $\mathrm{~N}$ & $\mathrm{~N}$ & $\mathrm{~N}$ \\
\hline 18 & $\mathrm{~N}$ & $\mathrm{~N}$ & $\mathrm{~N}$ \\
\hline 19 & $\mathrm{~N}$ & $\mathrm{~N}$ & $\mathrm{~N}$ \\
\hline 20 & $\mathrm{~N}$ & $\mathrm{~N}$ & $\mathrm{~N}$ \\
\hline
\end{tabular}

て大きい事故率を呈していることが見てとれる．また， 単純析橋で車速が $100 \mathrm{~km} h$ の際の事故率が 0.53 ということ は2台に1台以上は事故を起こしているので非常に大きな 事故率である。

\section{4. 事故率減少と橋梁構造の考察}

\section{(1) 事故分析}

a) スリップに起因した事故 (Case(1)，Case(4))の分析

それぞれの車速の事故ケースの中で一番多くを占めて いるスリップに起因した事故について分析寸る.まず, 事故につながったスリップが発生した時間について検討 した．まず，連続析橋において各時間（0.5秒刻み）で 事故につながったスリップが発生し始めたケース数をま とめたものを図-15に示す．ほとんどのケースで事故に つながったスリップが7.0秒から8.0秒にかけて発生して いる．これは，7.0秒付近で支承が破壊し，衝突現象が 発生し始めることが一つの原因である。また，図-16に 示した7.0秒と8.5秒の際の変形図より桁の水平方向の回 転運動が発生していることが確認された。これも，7.0 秒から8.0秒にかけてスリップが多発している一つの原

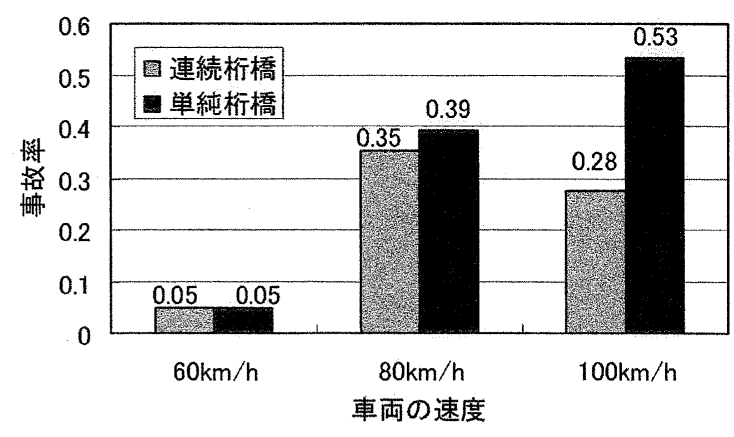

図-14 各車速での事故率

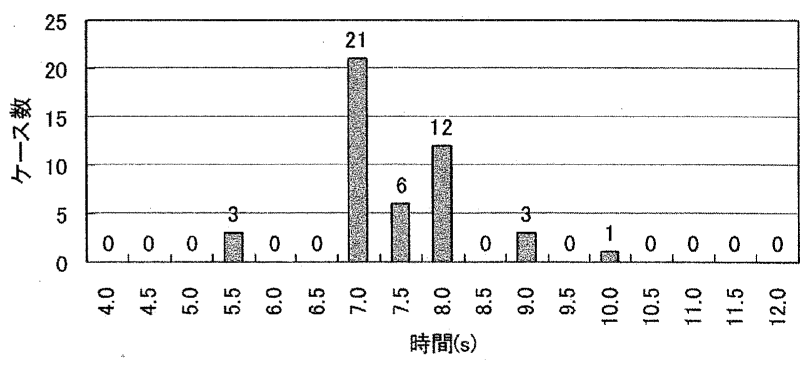

図-15 時間ごとのスリップ発生数

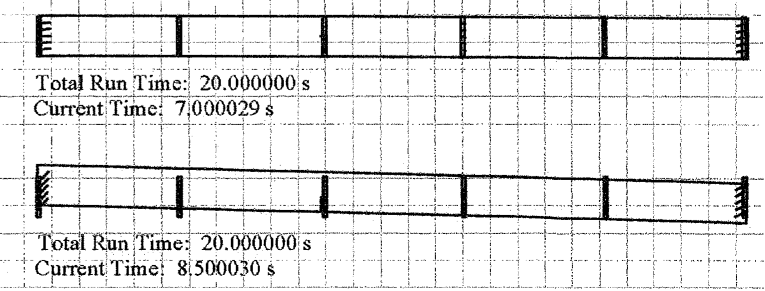

図-16 桁の変形図 
因であると考えられる．図-16 で析の回転挙動が生じて いるのは，3 成分の地震動を入力している鷹取波の特性 によるもので, 外力のベクトルが橋桁バイヤス方向に働 き，桁の角が橋台に衝突することに起因している．これ らは単純桁橋でも同じ傾向が得られた。

b）桁-橋台間および桁間の橋軸直角方向のずれに起因し

\section{た事故の分析}

Case(2)および Case(5)の事故である桁-橋台間および桁 間の橋軸直角方向のずれ量について検討した，それぞれ のケースで車両が事故を起こした際の橋軸直角方向のず れ量をプロットしたものを図-17 に示寸．車速が $80 \mathrm{~km} / \mathrm{h}$ で事故を起こしたケースでは桁-橋台間および析間の橋 軸直角方向のずれ量が全て $1.0 \mathrm{~m}$ 以上になっていること が分かる. また，車速 $100 \mathrm{~km} /$ で事故を起こしたケース でも一部を除いて $1.0 \mathrm{~m}$ 以上の大きな值になっているこ とが見てとれる.この $1.0 \mathrm{~m}$ という值は車両モデルの幅 が $1.705 \mathrm{~m}$ で車線の幅が $3.6 \mathrm{~m}$ であることから，左右の余 裕量が 0.94mになっていることに起因している.

\section{（2）橋軸直角方向の変位制限装置}

道路橋示方書では，橋軸直角方向の変位制限構造につ いて以下のように規定している 1).「一般に橋軸直角方 向には，桁が移動して落橋する可能性は極めて低いため, タイプ B の支承を用いる場合には，この方向には変位 制限構造を設ける必要はない. ただし, 斜橋や曲線橋,

下部構造の頂部幅が狭い橋，1 支承線上の支承の数が少 ない橋, さらに地盤の流動化の影響により橋軸直角方向 に橋脚の移動が生じる可能性のある橋では，橋軸直角方 向への移動を伴って落橋が生じる可能性があることから, タイプ B の支承を用いる場合においても，この方向に ついて変位制限構造を設ける必要がある」。つまり，橋 軸直角方向一の落橋の可能性がある場合の久变位制限構 造を設けなければならないと規定している。これに従う と, 本研究でモデル化している橋梁に関しては橋軸直角 方向の変位制限構造は設けなくてもよいということにな る. また，現在の設計では，免震化されている橋であっ ても，サイドブロックを設置して橋軸直角方向には非免

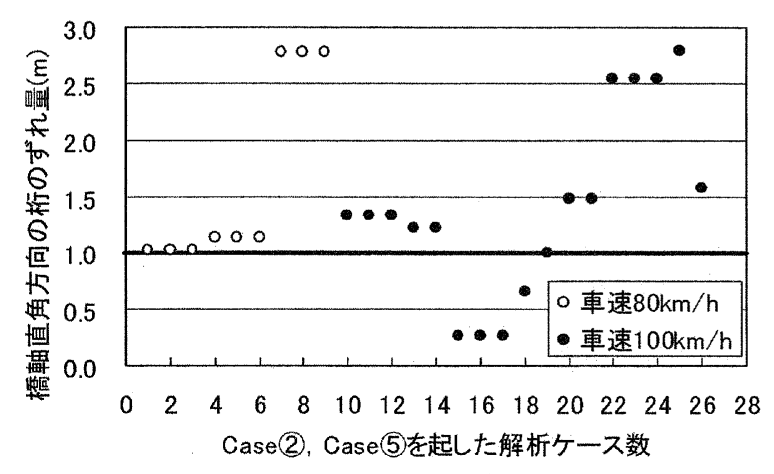

図-17Case(2)および(5)の橋軸直角方向のずれ量
震となっている橋梁も多い. しかし, 橋軸直角方向の変 位制限構造を設けることにより，桁の回転運動および橋 軸直角方向の $1.0 \mathrm{~m}$ 以上のずれ量を防ぐことができ，ド ライバーの安全性向上に繫がる.

そこで，変位制限構造をモデル化し，ドライバーの安 全性について検討を行う，変位制限装置は，支承が損傷 した場合に速やかに働くものとし，ゴム支承の許容せん 断ひずみを変位制限構造が効き始める量としてモデル化 した．解析ケースとしては上記で示した事故率が一番高 かった連続析橋での車速が $80 \mathrm{~km} /$ であるケース，単純 析橋での車速が $100 \mathrm{~km} /$ であるケースで解析を行った。

橋軸方向の析の開きに起因している事故を防止するため に伸縮装置の受け持ち量は支承の許容せん断ひずみ值と した.

連続桁橋, 単純析橋で橋軸直角方向の変位制限構造を 考慮した場合としていない場合の事故率を比較したもの をそれぞれ図-18，図-19 に示す．連続桁橋，単純桁橋 ともに事故率が低減されていることが分かる．さらに， 連続桁橋のほうが減少率は大きいことが分かる。単純桁 橋では橋軸直角方向の変位制限構造を考慮した後でも全 体での事故率が 0.4 となっている. これは，衝突現象な どによる影響が大きいことに起因している.さらに，こ の值は連続桁橋での全ケースでの事故率よりも大きい. このことよりドライバーの観点から考えると単純析橋に 対しては桁を連続化することも安全性向上の有効な手段 であると言える。

\section{(3) 固定支承}

単純桁橋では桁の大きな変位に起因している衝突現象
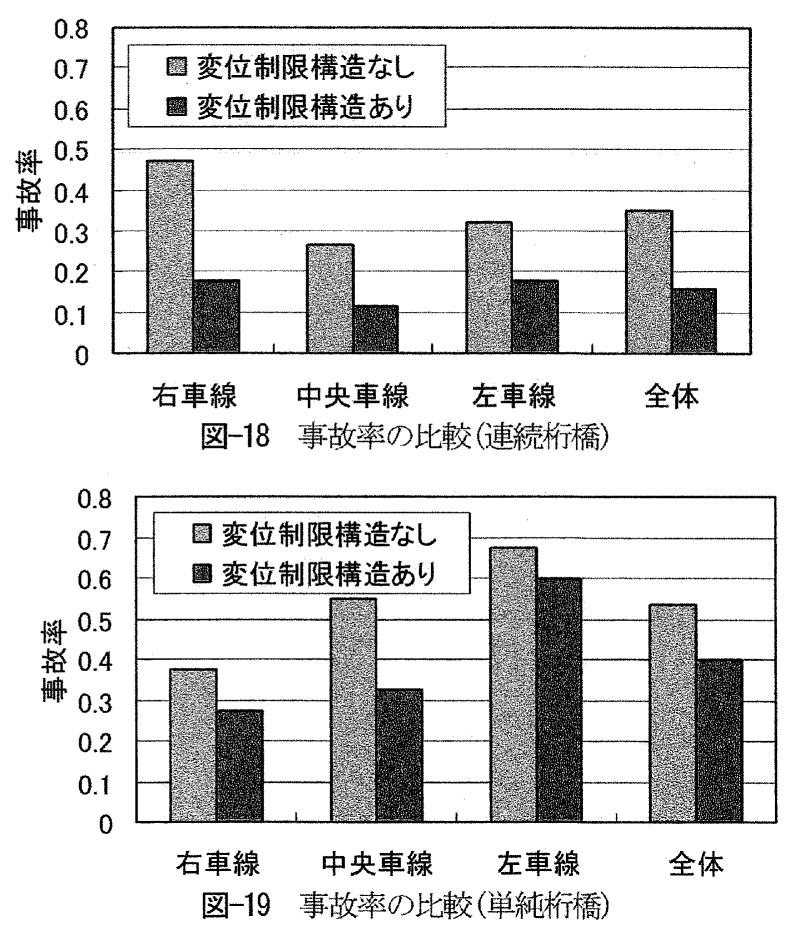
などの影響がドライバーの安全性に関わってくる.そこ で支承部に固定支承を用いた際の事故率について検討を 行う. 固定支承については, 支承の水平方向および鉛直 方向の剛性を無限大とすることで拘束条件を表現した. また，この支承に関しては支承が破壊寸ることは考慮し ていない. 固定支承などを用いると大地震発生時に橋脚 に加わる力が大きくなり塑性変形を起す可能性も高くな る. そこで橋脚における塑性領域の影響を考慮する. 塑 性変形やひび割れは，部材の剛性を減少させて解析を行 う.すなわち, 橋脚柱の断面2次モーメントを減少させ ることによって等価線形解析として考慮する. この断面 2次モーメントは, 道路橋示方書 ${ }^{1)}$ の3.3.2 に示寸曲げ変形 による降伏剛性（降伏水平耐力と降伏水平変位の比）に よって決定した. 具体的な数值を表-12に示す.

上記の解析結果の一例として桁-A1 橋台間の橋軸およ び橋軸直角方向の相対変位を図-20に示す．これより,橋 軸方向，橋軸直角方向ともに非常に小さな值であること が分かる. 固定支承を用いた橋梁では桁の変位が非常に 小さくなることが分かる．本モデルを用いて事故率を算 出した．事故率を検証する対象の車両は車速 $100 \mathrm{~km} / \mathrm{h}$ の 車両とした，また，支承の剛性が無限大であることなど から連続桁橋と単純桁橋で桁の応答はほぼ一致する. よ って，固定支承を用いた際の橋梁モデルは 1 ケースとし た（以降，固定支承モデルと呼ぶ）。

固定支承モデルでの事故率を図-21 に示寸. 固定支承 モデルでは橋脚や桁には大きな断面力が発生することに なるが，橋梁の固有周期が小さくなれば変形も小さくな るため事故率は極めて小さく抑えることが可能である.

\section{(4) 段差防止構}

道路橋示方書では，段差防止構造について以下のよう に規定している ${ }^{1)}$. 「段差防止構造は，支承が破損した 場合でも上部構造を適切な高さに支持できる構造とする 大地震発生後において住民の緊急避蜼や緊急車両の通行 をできる限り可能と寸るために，橋が被害を受けた場合

表-12 橋脚の断面 2 次モーメント

\begin{tabular}{|l|c|c|}
\hline & 橋軸方向: Ix & 橋軸直角方向: Iy \\
\hline 断面2次モーメント $\left(\mathrm{m}^{4}\right)$ & 1.98 & 10.22 \\
\hline
\end{tabular}
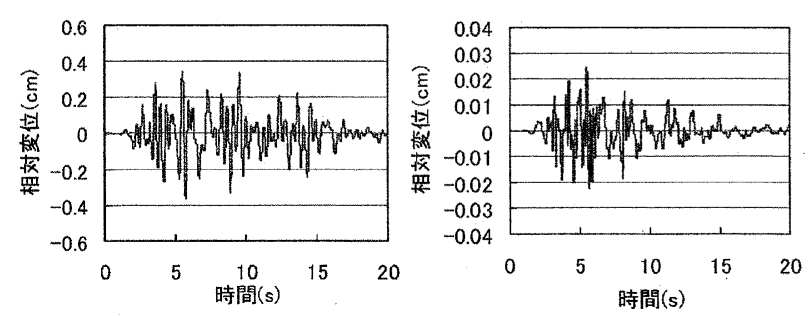

(a)橋軸方向（地震動 NS成分）(b)橋軸直角方向（地震動 EW 成分）

図-20 桁-A1 橋台間の相対変位
にも路面に発生する段差を極力抑えることは防災上重要 である.このための措置が段差防止構造の設置であり， 支承高が大きい支承を用いる場合には設けることが望ま しい」，つまり，地震発生後の道路の機能を保持させる ことを目的として規定されている. 大地震発生時に高架 橋を走行している車両が存在する可能性は極めて高いが 車両の安全走行の観点は配慮されていない。

本研究の解析モデルでは支承破壊後に桁が支承から落 下寸ることは考慮していない，しかし，兵庫県南部地震 の際などには支承が破壞に至っている数多くのケースが 存在していることより, 支承破壇後に桁が支承から落下 する可能性が高いことは容易に想像できる，そこで支承 破壊後に桁が支承から落下したと仮定寸ると掛讨違え部 で $0.1 \mathrm{~m}$ 程度の段差（支承高さ $0.097 \mathrm{~m}$ ） が発生する. 一 方, 図-8 に示したタイヤの許容落下量は許容段差量と も考えられる. そこで $0.1 \mathrm{~m}$ の段差を通過できる一番早 い車两速度を求めると図-8 より $18.06 \mathrm{~m} / \mathrm{s}(65 \mathrm{~km} / \mathrm{h})$ であ ることが分かる. よって $65 \mathrm{~km} / \mathrm{h}$ 以上の速度であるとこ の段差を安全に通過できない. 逆に段差が $0.05 \mathrm{~m}$ 以下で あるとほとんどの車速（100km/h 以下）で通過できるこ とが分かる.よって, 段差防止構造により支承破壊後に 発生する段差が $0.05 \mathrm{~m}$ 以下に抑えることは，ドライバー の安全性を向上する上で有効な手段であると考えられる.

\section{5. まとめ}

ある連続析橋，単純桁橋を対象として，その支承破壊 後まで考慮して解析を行い, ドライバーの危険度を算出 した. 本解析には, 新潟県中越地震の際のアンケート調 查より得られたドライバーの地震時の反応特性を解析に 組み入れた. さらに, 地震時にゴム支承を有する高架橋 上を走行するドライバーに潜んでいる危険を分析し，ド ライバーの視点での橋梁の安全性向上のための対策法に つい提案, 検討した. 得られた知見を以下に示寸.

1) 地震発生時の車速が60km $\mathrm{h} の$ ケースでは, 地震動が 強震域に達寸る前にほとんどのケースで停車してい るために事故は発生しにくいことが知られた. 本研

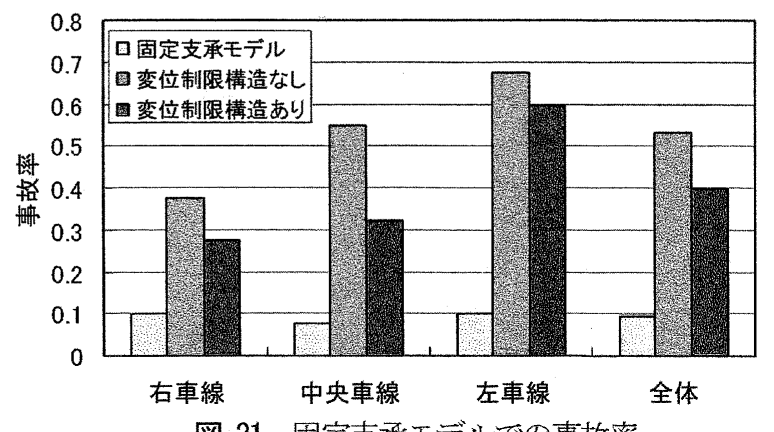

図-21 固定支承モデルでの事故率 
究の車線幅モデルよりも狭い自動車専用道路では, 走行車線を冕脱する可能性が高くなると考えられる。

2) 車速が $80 \mathrm{~km} / \mathrm{h}$ 以上では連続桁橋に比べて単純桁橋の 事故率が高く, ドライバーにとっては単純桁橋のほ うが危険であることが分かった．とくに単純桁橋を 時速 $100 \mathrm{~km} / \mathrm{h}$ で走行中の車両の事故率は 0.53 と高く, 単純桁橋を時速 $100 \mathrm{~km} / \mathrm{h}$ で走行中の車両が地震動を受 けるとかなり危険であるといえる。

3）事故ケースを分析した結果，連続桁橋および単純桁 橋ともにスリップに起因している事故が圧倒的に多 いことが示された.

4) 橋軸直角方向の変位制限構造を考慮した後でも単純 桁橋では全体での事故率が 0.4 であったことから，単 純桁橋の桁を連続化することは車両安全性向上の有 効な手段である。また，連続化した橋梁に橋軸直角 方向の変位制限装置を設置することも有効である.

5) 桁間および桁-橋台間の衝突現象や支承破壊などの大 きな枌の変位が生じないと仮定（固定支承モデルの 適用）すれば，車両の事故率が0.1程度と小さくなる.

6) 道路橋示方書で示されている段差防止構造に対して, ドライバーの安全性の観点からみると支承破壊など によって $0.05 \mathrm{~m}$ 以上の段差が生じる可能性がある場合 は段差防止構造を設ける必要がある。

本研究の解析モデルや危険度の算定には，いくつかの 仮定事項が含まれている.今後は，これらの事項の妥当 性について，詳細に検証することが必要である.

\section{参考文献}

1) 社団法人日本道路協会 : 道路橋示方書 - 同解説, V 耐震 設計編, 丸善, 1996.

2）渡辺学歩，川島一彦：衝突ば叔を用いた桁間衝突の解析 精度, 第 2 回地震時保有耐力法に基づく橋梁の耐震設計 に関するシンポジウム講演論文集, pp.443-448，1998.

3) 武野志之歩, 伊津野和行 : 衝突速度スペクトルによる桁 間衝突の評価と衝突ばねのモデル化が及ぼす影響, 第 4 回地震時保有耐力法に基づく橋梁の耐震設計に関するシ
ンポジウム講演論文集, pp.493-498, 2000.

4) 高田至郎, 宝角正明, ラダン・イワノフ: 落橋防止構造 に作用する地震力上信頼性評洒, 建設工学研究所論文報 告集 第43-B号, pp.69-82, 2001.

5）川谷充郎，山田靖則，獤下裕一：三次元車両モデルによ る桁橋の動的応答解析, 土木学会論文, No.584/I-42, pp.7986, 1998.

6) 川谷充郎，山田靖則，金哲祐，川木秀昭 : 道路橋交通振 動の三次元解析による床板応答の評価，構造工学論文集， Vol.44A, pp.827-834, 1998.

7) 丸山喜久, 山崎文雄 : ドライビングシミュレータを用い た地震時車両走行模擬実験, 日本地震工学シンポジウム 論文集，第11回，pp.2283-2288，2002.

8）丸山喜久，山崎文雄 : ドライビングシミュレータを用い た地震時運転者の反応特性に関する基礎的検討, 土木学 会地震工学論文集, Vol.27, pp.1-8, 2003.

9) 丸山喜久, 山崎文雄, 山之内宏安: 高速道路走行車両の 地震応答解析, 土木学会論文集, No. 696/-58, pp.149-260, 2002.

10) Ivanov, R. and Takada, S. : Assessment of the vulnerability of jointed D.I.P. crossing active faults, 土木学会地震工学論文集, Vol.27, pp.1-6,2003.

11) 伯野元彦: 破壊のシミュレーション, 森北出版, 1997.

12) 山本聡, 高田至郎, 鍬田泰子: 橋梁桁上に停止する車両 の地震応答とドライバーの安全性, 建設工学研究所論文 報告集，第46-B号，pp.171-188，2004.

13）日本交通安全協会：ルールとマナー，2002.

14）高田至郎, 鍬田泰子, 山本聡 : 新潟県中越地震の際のド ライバー安全性の分析 〜アンケート調査と解析一の反 映〜, 神戸大学都市安全研究センタ一研究報告, 第 9 号, pp.353-634, 2005.

15）高田至郎，鍬田泰子：人的被災軽減のための DFH 法を用 いた家屋崩噮プロセス・シュミレーション, 第 26 回地震 工学研究発表論文集, pp.1445-1448, 2001.

\section{ANALYTICAL STUDY ON ACCIDENT OCCURRENCE RATE OF RUNNING CARS ON BRIDGE GIRDERS DURING EARTHQUAKES}

\section{Shiro TAKADA, Satoshi YAMAMOTO and Yasuko KUWATA}

Based on lessons from a large number of bridge failures during the 1995 Kobe earthquake, rubber bearings and isolation bearings have been rapidly adopted in new bridges as well as existing ones. The bridge with new bearings is expected to cause longer natural period of superstructure and larger response displacement of girders. However, few researches have done on behaviors of automobile running on elevated bridge under strong ground motions. This research examines measures to improve seismic resistance of elevated bridge from the viewpoint of driver's safety. 